ORNL/M-4322

OAK RIDGE

NATIONAL

LABORATOPY

MARTIN MARIETTA
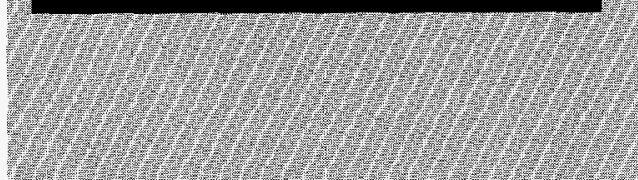

(1)
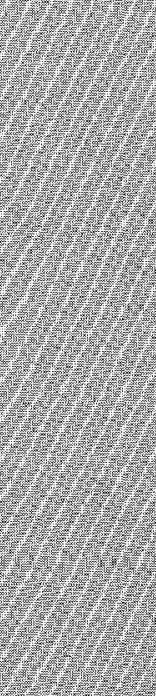

1.1.

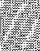

Pr.

MALAGED BY

MARTI MARIETTA EIEERG SYSTEUS, INC.

EOR THE UNITED STATES

DEPARTMENT OF ENERGY
RECEIVED

OCT 131995

OSTI

\section{What Is Plutonium Stabilization, and What Is Safe Storage of Plutonium?}

Dr. Charles W. Forsberg

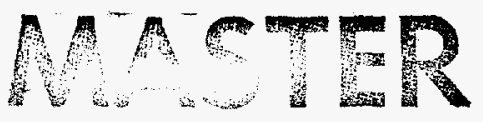

DISTRISUTION OF THS DOCUMENT IS UNLIMED

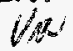


This report has ben reproduced directly from the best available copy.

Available to DOE and DOE contractors from the Office of Scientific and Technical Information, P.O. Box 62, Oak Ridge, TN 37831 ; prices available from (615) 576-8401, FTS 626-8401.

Availabie to the public from the National Technical Information Service, U.S. Department of Commerce, 5285 Port Royal Rd., Springfield, VA 22161.

This repcrt was prepared as an account of work sponsored by an agency of the United States Government. Neither the United States Government nor any agency thereot, nor any of their employees, makes any warranty, express or implied. or assumes any legal liability or responsibility for the accuracy, completeness, or usefulness of any information, apparatus, product, or process disclosed, or represents that its use would not infringe privately owned rights. Reference herein to any specific commercial product, process, or service by trade name, trademark, manufacturer, or otherwise, does not necessarily constitute or imply its endorsement, recommendation, or favoring by the United States Government or any agency thereof. The views and opinions of authors expressed herein do not necessarily state or reflect those of the United States Government or any agency thereof. 


\section{DISCLAIMER}

Portions of this document may be illegible in electronic image products. Images are produced from the best available original document. 


\title{
WHAT IS PLUTONIUM STABILIZATION, AND \\ WHAT IS SAFE STORAGE OF PLUTONIUM?
}

\author{
Dr. Charles W. Forsberg \\ Oak Ridge National Laboratory* \\ P. O. Box 2008 \\ Oak Ridge, Tennessee 37831 \\ Tel: (615) 574-6783 \\ Fax: (615) 574-3431 \\ Email: forsbergcw@ornl.gov
}

\author{
Discussion Paper \\ for the U.S. Department of Energy \\ Research Committee for the Stabilization of Nuclear Materials
}

June 29, 1995

"Managed by Lockheed Martin Energy Systems, Inc., under contract DE-AC05-84OR21400 for the U.S. Department of Energy. 



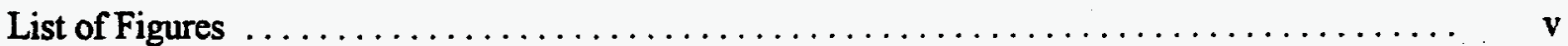

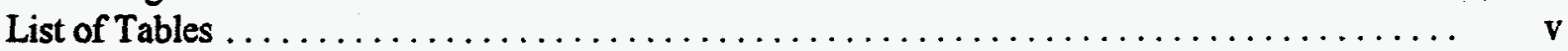

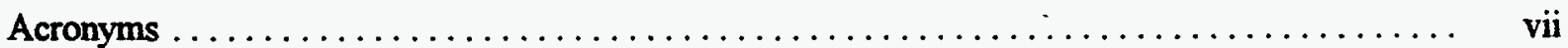

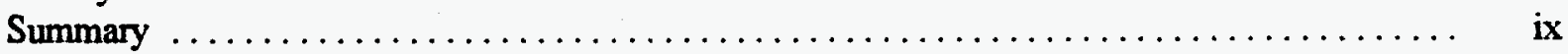

1. INTRODUCTION $\ldots \ldots \ldots \ldots \ldots \ldots \ldots \ldots \ldots \ldots \ldots \ldots \ldots \ldots \ldots \ldots \ldots \ldots \ldots$

2. BACKGROUND $\ldots \ldots \ldots \ldots \ldots \ldots \ldots \ldots \ldots \ldots \ldots \ldots \ldots \ldots \ldots \ldots \ldots \ldots \ldots \ldots \ldots$

3. RELATIONSHIPS BETWEEN AND AMONG GOALS, OPTIONS, HAZARDS, TECHNICAL CRITERIA, AND STABILIZATION $\ldots \ldots \ldots \ldots \ldots \ldots \ldots \ldots \ldots \ldots$

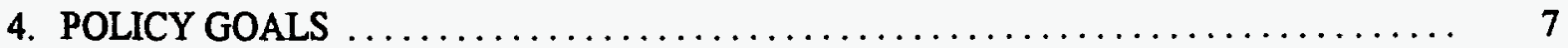

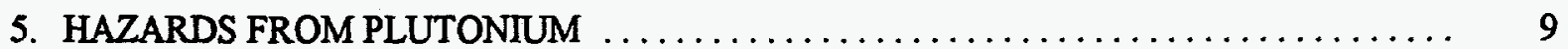

6. TECHNICAL PLUTONIUM STORAGE OPTIONS $\ldots \ldots \ldots \ldots \ldots \ldots \ldots \ldots \ldots \ldots \ldots$

6.1 PLUTONIUM STORAGE OPTIONS $\ldots \ldots \ldots \ldots \ldots \ldots \ldots \ldots \ldots \ldots \ldots \ldots \ldots$

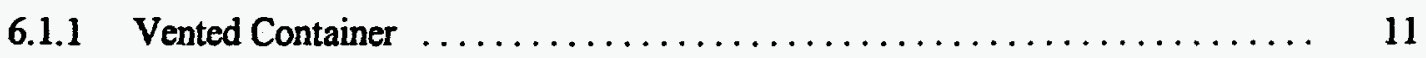

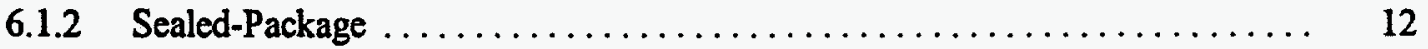

6.1.3 Plutonium Form $\ldots \ldots \ldots \ldots \ldots \ldots \ldots \ldots \ldots \ldots \ldots \ldots \ldots \ldots \ldots \ldots$

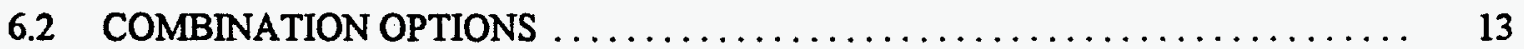

6.3 EXPERIENCE FROM OTHER FIELDS $\ldots \ldots \ldots \ldots \ldots \ldots \ldots \ldots \ldots \ldots \ldots \ldots \ldots \ldots \ldots$

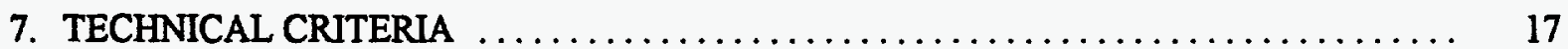

7.1 DERIVATION OF TECHNICAL CRITERIA $\ldots \ldots \ldots \ldots \ldots \ldots \ldots \ldots \ldots \ldots \ldots \ldots$

7.2 RISK AND TECHNICAL CRITERIA $\ldots \ldots \ldots \ldots \ldots \ldots \ldots \ldots \ldots \ldots \ldots \ldots \ldots \ldots$

7.2.1 Relationship Between Criteria and Risk ..................... 17

7.2.2 Plutonium Form Technical Criteria $\ldots \ldots \ldots \ldots \ldots \ldots \ldots \ldots \ldots \ldots \ldots$

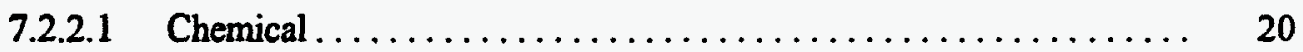

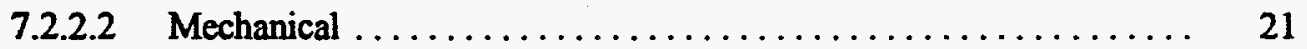

7.2.2.3 Nuclear Criticality .......................... 21

8. PLUTONIUM STORAGE STANDARDS AND STABILIZATION $\ldots \ldots \ldots \ldots \ldots \ldots \ldots$

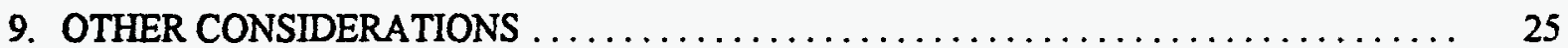

9.1 RISK TRADE-OFFS: REDUCTION OF FAILURE PROBABILITIES VERSUS REDUCTION OF ACCIDENT CONSEQUENCES 


\section{CONTENTS (continued)}

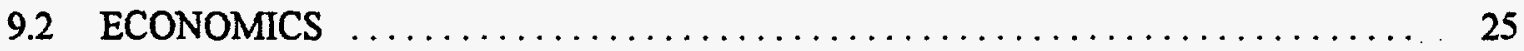

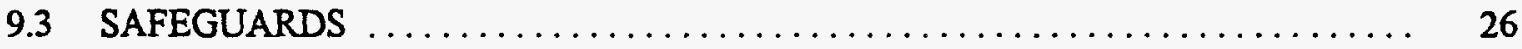

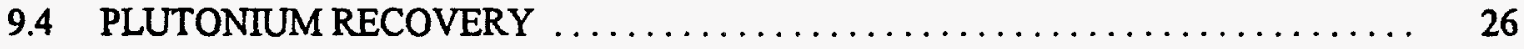

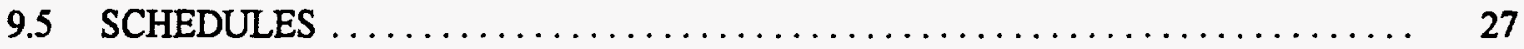

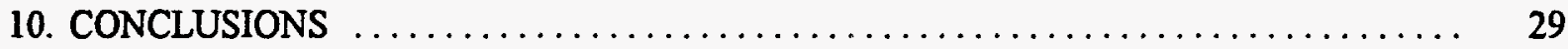

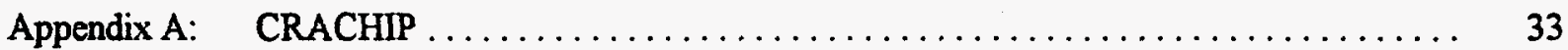




\section{List of Figures}

Fig. 1 Relationships between and among goals, options, hazards, technical criteria, and standards

Fig. 2 Long-term plutonium stabilization form criteria based on source of risk $\ldots \ldots \ldots \ldots$

Fig. 3 CRACHIP storage block within plutonium storage vault $\ldots \ldots \ldots \ldots \ldots \ldots \ldots \ldots$

\section{List of Tables}

Table 1 Relationship between technical screening criteria for plutonium forms and ES\&H risks from storing plutonium $($ risk $=$ probability $\times$ consequences $) \ldots \ldots \ldots \ldots \ldots$ 



\section{Acronyms}

CRACHIP CRiticality, Aerosol, CHemically Inert Plutonium

DNFSB Defense Nuclear Facilities Safety Board

DOE Department of Energy

ES\&H Environment, safety, and health

HLW High-level waste

MOX Mixed oxide

ORNL Oak Ridge National Laboratory

SRS Savannah River Site

U.S. United States 



\section{SUMMARY}

The end of the cold war has resulted in the shutdown of nuclear weapons production and the start of dismantlement of significant numbers of nuclear weapons. This, in turn, is creating an inventory of plutonium requiring interim and long-term storage. A key question is, "What is required for safe, multidecade, plutonium storage ?" The requirements for storage, in turn, define what is needed to stabilize the plutonium from its current condition into a form acceptable for interim and long-term storage. Storage requirements determine if research is required to (1) define required technical conditions for interim and longterm storage and (2) develop or improve current stabilization technologies.

Storage requirements depend upon technical, policy, and economic factors. The technical issues are complicated by several factors. Plutonium in aerosol form is highly hazardous. Plutonium in water is hazardous. The plutonium inventory is in multiple chemical forms-some of which are chemically reactive. Also, some of the existing storage forms are clearly unsuitable for storage periods over a few years. Gas generation by plutonium compounds complicates storage: (1) all plutonium slowly decays creating gaseous helium and (2) the radiation from plutonium decay can initiate many chemical reactions-some of which generate significant quantities of gases. Gas generation can pressurize sealed storage packages. Last, nuclear criticality must be avoided.

Three mainline approaches for safe storage have been identified:

- Storage in vented containers. The container provides a primary barrier to prevent the release of plutonium aerosols to the atmosphere or plutonium dissolution in groundwater. The plutonium is stabilized to ensure container integrity. Stabilization ensures that there are (1) no liquids and, hence, no potential for leaks; (2) low rates of corrosion of the container; and (3) no possibility of rapid chemical reactions that could damage the container or release materials. Controlled filtered venting allows the escape of (a) helium and (b) gases generated by radiation-induced chemical reactions. Nuclear criticality control is ensured by (1) limiting quantities of plutonium per container and (2) geometric spacing of containers in storage areas. Safety and environmental protection are also dependent on facility conditions and operations to (1) protect the package integrity from external events, (2) ensure proper operation of vents, and (3) avoid nuclear criticality.

- Storage in sealed packages. The sealed package provides a primary barrier to prevent the release of plutonium aerosols to the atmosphere or plutonium dissolution in groundwater. The plutonium is stabilized to ensure sealed-package integrity. Stabilization ensures that there are (1) no liquids, (2) low rates of corrosion of the package, (3) no possibility of rapid chemical reactions, and (4) minimal generation of gases from chemical reactions. Limited helium buildup from radioactive decay and consequent pressurization of the container are allowed by use of strong-wall containers. Nuclear criticality control is ensured by (1) limiting quantities of plutonium per container and (2) geometric spacing of packages in storage areas. Safety and environmental protection are also dependent upon facility conditions and operations to (1) protect the integrity of the package from external events and (2) avoid nuclear criticality. 
- Storage in a monolithic solid chemical form. The plutonium form by itself provides the primary barrier to prevent the release of plutonium aerosols to the atmosphere, plutonium dissolution in groundwater, and nuclear criticality. The chemical form (1) is chemically inert, (2) does not generate gases from chemical reactions, (3) traps helium gas from radioactive decay within the chemical structure, (4) is monolithic with no fine particulates, and (5) contains neutron poisons sufficient such that nuclear criticality can not occur. Such forms, known as CRiticality, Aerosol, $\mathrm{CHemically} \mathrm{Inert}$ Plutonium (CRACHIP), may be stored in vented containers or sealed packages. Safety and environmental protection are not strongly dependent upon facility conditions and operations, where the plutonium is stored in a CRACHIP form.

Plutonium can be safely stored by any of the previous methods. However, for equivalent levels of safety and environmental protection, the facility and operational requirements are very different for each option. The operational requirements for storage options vary from maintenance of glovebox processing and handling capabilities to sealed-vault storage with minimal requirements beyond security. There are policy issues associated with the choice of option. Some of the important issues are:

- How much should safety depend upon human activities into the future? The three different storage options for equivalent levels of worker, public, and environmental safety have very different degrees of dependence upon strict administrative controls, good operations, and steady funding levels. Thus, the choice of options also has major implications on how many support facilities are required at a site with significant plutonium inventories.

- Is the goal to minimize plutonium risks (probability of an accident times the consequences of an accident), or should more emphasis be placed on avoidance of higher consequence accidents?

Added detail is provided herein on the CRACHIP option because the other storage options have been in use for short-term storage during the many decades of weapons production. 


\section{INTRODUCTION}

The end of the cold war has resulted in the shutdown of nuclear weapons manufacturing in the United States, the ensuing disassembly of excess nuclear weapons, and the storage of plutonium in multiple chemical forms. Plutonium left within the production complex when the complex was shut down has been stored in a variety of forms-some clearly unsuitable for either interim or long-term storage. Examples include (1) plutonium in plastic containers that degrade in time because of radiation damage and (2) plutonium in liquid solutions from which the plutonium slowly precipitates. Therefore, a need exists to stabilize these materials for storage. Stabilization will minimize health and safety risks to workers, the public, and the environment.

The historical perspective has been that the United States did not have supplies of plutonium sufficient to meet U.S. policy objectives. Consequently, by definition no significant inventories of plutonium existed that required extended storage-although, in some cases, plutonium was stored for extended periods because of unexpected events. Because there was no need to consider interim and long-term storage of plutonium, methods and standards for interim and long-term plutonium storage were not developed.

If plutonium is to be stabilized for storage, the question arises, "What is required for safe interim and long-term storage of plutonium in multiple chemical and physical forms?" This question is central (a) to any plans for plutonium storage and (b) to defining any research requirements to support stabilization and storage. Stabilization is the process to convert plutonium from its current forms into forms that meet interim and long-term storage goals. This paper considers these questions. 


\section{BACKGROUND}

To address plutonium research and development (R\&D) stabilization issues, the U.S. Department of Energy (DOE) has established the Research Committee for the Nuclear Materials Stabilization Task Group. ${ }^{1}$ The charter of the research committee includes:

"Assessing the stabilization program as outlined in the Implementation Plan for Defense Nuclear Facilities Safety Board (DNFSB) Recommendation 94-1 for research and technology needs, ${ }^{2}$ current and planned research and development efforts appropriate to the stabilization program, commercially available technologies that are directly applicable, and known or planned standards for storage and disposition of materials."

This paper was prepared to clarify issues associated with stabilization and storage of plutonium in different forms. 


\section{RELATIONSHIPS BETWEEN AND AMONG GOALS, OPTIONS, HAZARDS, TECHNICAL CRITERIA, AND STABILIZATION}

Four types of input information are required to determine if plutonium is being stored safely and whether plutonium stabilization is required: policy goals, hazards of plutonium, storage options, and chemical and nuclear composition of the plutonium to be stored. With these inputs, plutonium storage safety can be evaluated. If the plutonium meets storage policy goals, the plutonium does not need to be stabilized. If the plutonium is in forms that are not suitable to meet storage goals, it must be stabilized (processed) to meet those goals. The relationship between goals, technical criteria, standards, and stabilization are shown in Fig. 1.

Policy goals define the top-level requirements-how safe is safe, and under what conditions should safety be ensured. Hazards are the risks from plutonium to man and the environment. Options define different technical approaches to ensure the safe storage of plutonium by preventing any hazards of plutonium from impacting human health or the environment. For plutonium storage, three possible barriers prevent a release of plutonium to man and the environment: the plutonium form, the package, and the building and its ventilation systems. Different combinations of plutonium forms, packages, and buildings define options. Each barrier to the release of plutonium to the environment has its own set of technical-screening criteria, which define those specific technical factors important to safety and environmental protection using a particular option.

Given a set of policy goals and technical options, acceptable storage options are selected. Different goals imply that different options with different sets of technical-screening criteria are important. For example, if the goals include minimization of long-term storage costs, the building and its ventilation systems should not be the primary barrier to a release of plutonium to the environment. In production operations, the building and gloveboxes are the primary barriers to a release of plutonium to the environment. This is a workable strategy, but it implies high operation costs. If the purpose of the building is limited to security, building operating costs are much reduced.

The choice of goals and options determines plutonium storage standards for the plutonium form, package, and building. If plutonium is to be stored in a glovebox, there are few requirements on the form of the plutonium. If the plutonium is to be stored in sealed packages to minimize storage costs, there are added requirements on the plutonium form such as (1) the plutonium must not be in a form corrosive to the package and (2) the plutonium form must not generate large quantities of gases that would pressurize the package and cause its failure. Given plutonium storage standards, each lot of plutonium can be compared to those standards. If the plutonium meets the standards, nothing must be done. If the plutonium does not meet the standards, it must be stabilized (processed) until the standards are met. 


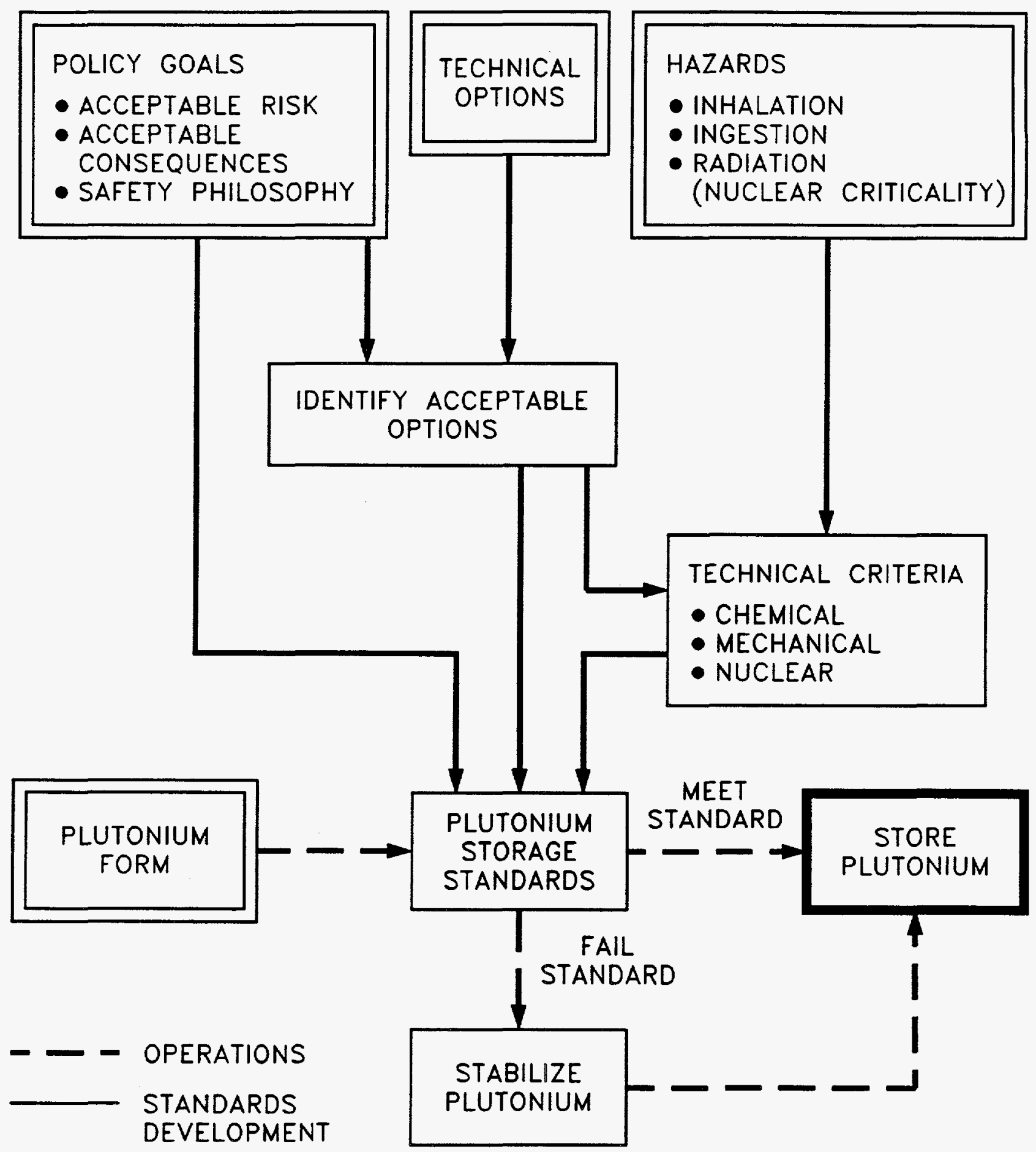

Fig. 1. Relationships between and among goals, options, hazards, technical criteria, and standards. 


\section{POLICY GOALS}

The goal is the safe storage of plutonium such that the workers, the public, and the environment are protected. Stabilization is the technical process to convert plutonium in current forms into forms acceptable for interim and long-term storage. Stability has multiple definitions. The most appropriate definition may be "resistance to chemical change or to physical disintegration."4

There are different degrees of stabilization with different end points. These varying end points have significantly different implications in terms of risk, cost, and other parameters. Stabilization can vary from converting highly chemically reactive forms of plutonium to (1) relatively nonreactive forms for storage in vented containers to (2) chemically and neutronically inert plutonium forms in packages that can be stacked like cord wood in secure vaults. There are usually (but not always) trade-offs between short-term costs to stabilize materials and long-term storage costs. Two military examples can clarify that safe, secure storage is not a single end point, but a set of end points where the preferred end point depends upon goals.

- The military uses several different storage methods to store small arms. Weapons may be stored in racks for months to years, or weapons may be cleaned, coated with grease, and packed in boxes. Both methods can provide safe, secure storage. The packed-in-box option minimizes storage space and avoids any potential for corrosion of metal, but this option requires considerable preparation of weapons for storage and future use.

- The U.S. Navy stores its ships when they are not required. The navy has different categories of storage. In some situations, equipment is carefully maintained so that a ship can be made ready to sail in a relatively short time; in other situations mothballing is the preferred option. Mothballing includes activities such as draining fluids from tanks, placing special preservatives on components that may degrade, and backfilling empty spaces with inert gases. A ship in mothballs requires months to be made ready to sail, but mothballing avoids many routine maintenance costs which would be considerable over a long storage time.

Policy decisions define goals. With the goal of safe and environmentally acceptable plutonium storage, policy decisions must quantify safety in multiple dimensions:

- What is the acceptable risk of an accident? Risk in a technical context is defined as the probability of an accident occurring times the consequences of an accident.

- Is there a cutoff on the acceptability of high-consequence accidents? In terms of risk, a total of 10 injuries from a single accident every 1000 years (accident risk $=(10 \times 1) / 1000=0.01$ ) is equal to 10 accidents each with one injury every 1000 years (accident risk $=(1 \times 10) / 1000=0.01$ ). Societies, however, often place a higher value on prevention of large accidents. This reflects the greater difficulty of societies in managing large accidents compared to small accidents. 
- Is a particular approach to safety preferred? Different approaches to safety exist with different implications in terms of their dependence on maintenance of organizational competence and longterm financial commitments. Often there are trade-offs between short-term stabilization costs and long-term storage costs.

- Over what time period is reasonable assurance of safety desired?

- Do safeguards and security requirements-including international considerations-impose added requirements?

It is noted that the DNFSB 94-1 recommendations ${ }^{3}$ are in part a statement that goals, practices, and standards developed for production are not acceptable for long-term plutonium storage. Practices such as storing plutonium in plastic bottles or wrap may be acceptable during short-term production operations, but these practices are unacceptable for long-term storage because of the degradation of plastic with radiation and time. The end of the cold war has created a need to develop and implement plutonium storage standards with the requisite stabilization of plutonium to meet those standards. 


\section{HAZARDS FROM PLUTONIUM}

If plutonium is to be stored, the hazards of plutonium must be defined, and storage options thus address those hazards. There are three primary hazards:

- Inhalation. Plutonium is highly toxic if inhaled into the lungs. From the lungs, the plutonium can be transferred to the bone by the bloodstream. Alpha radiation from plutonium decay can (1) destroy lung and bone tissue and (2) cause cancer. The characteristics of the human throat and lung are such that only small particles are capable of reaching the lung and depositing in it. To avoid inhalation hazards, plutonium must not be allowed to escape in the form of small particulates.

- Ingestion. Plutonium is somewhat toxic if it is ingested in water or food. The risks of ingestion are less than inhalation because the human stomach only poorly absorbs plutonium into the blood stream.

- Criticality. If a critical mass of plutonium is formed in the correct geometry, nuclear chain reactions will be initiated, and radiation and heat will be generated. The heat blows the plutonium apart and shuts down the nuclear reactions. Experience and theoretical calculations indicate that criticality accidents are local events. Fatal doses of prompt radiation may occur within a few meters of the accident.

Hazards are often interconnected. Plutonium in water may generate plutonium-containing aerosols if the water evaporates and the plutonium is in certain chemical forms. Similarly, a major concern of nuclear criticality is that such events create plutonium aerosols and damage equipment that may allow a release of plutonium to workers, the public, and the environment beyond the immediate location of the accident.

All stabilization activities initiated for health and safety should be judged on the basis of lowering the risks from one or more of these hazards without significantly increasing the risks from other hazards. Included in such considerations must also be the risks of processing materials to more stable forms. 



\section{TECHNICAL PLUTONIUM STORAGE OPTIONS}

Three storage options are usually identified for long-term storage of plutonium: store in vented containers where the containers are the primary isolation barrier with building systems to handle off gases, store in sealed packages where the package is the primary isolation barrier, and store in stable plutonium

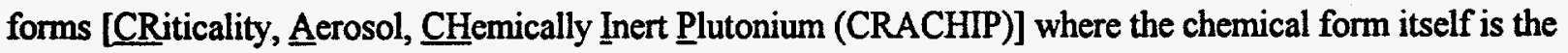
primary isolation barrier. For each option, there are different requirements for the plutonium form, storage package, and building. In practice, more that one of these options is likely to be used given the variety of chemical and physical forms of plutonium in the inventory.

The previously described options are recognized usually as acceptable. The vented-container and sealedpackage options are historical methods to store plutonium for short time periods between steps in plutoniummanufacturing operations. CRACHIP is a long-term storage option that has never been developed and implemented because there was never a need before for long-term plutonium storage.

\subsection{PLUTONIUM STORAGE OPTIONS}

\subsubsection{Vented Container}

Plutonium can be stabilized for storage in filtered vented containers by converting the plutonium to a solid form that has an acceptable chemical reaction rate with the storage container. The container provides a primary barrier to prevent the release of aerosols to the atmosphere or plutonium dissolution in groundwater. Plutonium is, however, a radioactive material, and that radioactivity (1) generates helium (i.e., alpha particles) as it decays and (2) can provide the energy to drive chemical reactions. Some chemical reactions generate gases (e.g., hydrogen) from degradation of plastics and hydrogen-oxygen mixtures resulting from the radiolysis of water. This implies that there will be generation of gases within the plutonium during storage and that the rate will depend upon the isotopics of the plutonium and the chemicals associated with the plutonium. Venting the container prevents the buildup of gas pressure inside the container. Such pressures could disperse the plutonium if the container were damaged.

Slow releases of gases generated within plutonium storage forms ensures a low potential for release of plutonium from the container by mechanisms such as entrainment of plutonium aerosols within the gas stream. The vented gases are filtered and treated.

Prevention of criticality for vented containers is ensured by (1) limiting the amount of plutonium in any one vented container below the quantities that could cause nuclear criticality and (2) facility procedures to ensure separation between containers in storage areas to prevent nuclear criticality. 
The requirements for this stabilization process are to (1) eliminate liquids that can leak from failed containers or accelerate the corrosion of containers and (2) eliminate the potential for rapid chemical reactions that could threaten the container integrity or result in a rapid gas release faster than the container-filtered venting system can handle. Rapid gas release can generate significant aerosols. Slow generation of gases by chemical reactions or helium by radioactive decay are acceptable because the package is vented.

\subsubsection{Sealed-Package}

Plutonium can be isolated in sealed packages, which provides a primary barrier to prevent the release of aerosols to the atmosphere or plutonium dissolution in groundwater. The plutonium form must prevent package failure by chemical corrosion. Overpressurization of the package by chemical reactions or radiationinduced chemical reactions must be avoided. The package is designed to withstand long-term pressure buildup from helium generation resulting from radioactive decay. The slow increase of pressure, over time, creates a potential energy source for plutonium dispersion if there is package failure, but the use of heavywalled packages makes this an unlikely event.

Stabilization requirements are more restrictive for the sealed-package option than for the ventedcontainers option. The plutonium must be in chemical forms in which significant gas generation from radiation-induced chemical reactions (hydrogen, oxygen, etc.) is limited to what the container can withstand. Helium production from radioactive decay is unavoidable; but it is a slow process. (Note: certain plutonium isotopes such as ${ }^{238} \mathrm{Pu}$ generate helium at a significant rate; hence, not all plutonium isotopes may be packaged in sealed containers for extended time periods.) However, thick-walled packages designed for high pressure allow the buildup of helium in the packages over decades.

There is significant historical experience in storing plutonium in sealed packages in two forms: metal and plutonium oxide. The metal-storage experience is primarily from the weapons community. The oxidestorage experience is from the manufacture of plutonium-enriched power reactor fuels. Significant quantities of plutonium have been stored without incident, but there have also been some package failures. The experience with what worked and what failed provides a reasonable level of confidence that plutonium metal and oxides can be packaged in sealed containers for reasonable storage periods without package overpressurization and package failure.

The current plutonium-metal and oxide-storage standard calls for sealed packages 5 . It is written for storage of relatively pure plutonium metal and plutonium oxide materials-not for residue and scrap. The sealed package prevents a release of plutonium aerosols or dissolution of plutonium in water. The package is designed to withstand increased pressure from gases generated by the plutonium storage form. The standard 
partly addresses nuclear criticality. The quantity of plutonium in any one package is limited to prevent nuclear criticality resulting from the plutonium within that package. Nuclear criticality can occur if a sufficient number of packages are placed close together. This type of nuclear criticality event is prevented by a combination of administrative controls and building design (separated storage holes) that limit how close packages of plutonium may be placed to each other within the facility.

\subsubsection{Plutonium Form}

Plutonium can be isolated from the environment for storage by converting it into plutonium forms wherein the chemical, mechanical, and nuclear forms of the plutonium become the first barrier to prevent aerosol release, groundwater contamination, or nuclear criticality. CRACHIP (a concept that is several decades old) defines the capabilities of these plutonium storage forms. Historically, no significant quantities of plutonium have required long-term storage; hence, CRACHIP was not considered as an option; therefore, the associated criteria have not been fully developed.

Two CRACHIP forms (Appendix A) have been identified that probably can be shown to meet these criteria in the near term:

- Plutonium glasses. Plutonium borosilicate glasses have been designed that meet such criteria. The experience for such plutonium forms is based on the use of glasses to immobilize radioactive and chemical wastes. By design, radiation-induced chemical reactions do not generate gases in these glasses. By design, helium is encapsulated as it is generated within the glass structure.

- Modified mixed oxides (MOX). Plutonium oxides with neutron poisons can be pressed into pellets and fired at high temperatures to create CRACHIP forms. The experience base for such plutonium forms is the manufacture of MOX fuel for nuclear power plants.

In the context of transportation, the plutonium form is recognized as important to safety. In the Code of Federal Regulations (10 CFR Part 71.63) plutonium in spent nuclear fuel is exempt from doublecontainment packaging requirements applicable to other plutonium forms. The basis in the rule making for this exemption is that the respirable fraction of plutonium in spent nuclear fuel is very small. The plutonium form is a barrier against release of plutonium to the environment. There is a legal and regulatory recognition of this option by the functional characteristics of certain plutonium-containing materials.

\subsection{COMBINATION OPTIONS}

The three approaches to safe store plutonium can be used in combination to reduce storage risks in different ways. 
- CRACHIP can be sealed in packages to provide full redundancy to guard against potential releases. This is the most conservative approach in that it provides (a) full protection from common mode failures and (b) the highest protection from plutonium release independent of human actions or facility conditions.

- A mix-and-match approach can be used. For example, the dominant worker health safety concern with plutonium is the risk of plutonium inhalation. One option is to store plutonium in sealed packages-but to forbid the storage of fine plutonium dust in the package. Here a greater level of conservatism in terms of storage requirements is provided to address the specific dominant hazard associated with plutonium handling and storage.

\subsection{EXPERIENCE FROM OTHER FIELDS}

Different fields have varying philosophies for the storage of hazardous materials. The experience of other industries can provide guidance and lessons learned. There is a large experience base in the use of radiation sources for medical, industrial, and research applications. Radioactive sources include ${ }^{137} \mathrm{Cs},{ }^{60} \mathrm{Co}$, ${ }^{252} \mathrm{Cf}$, and other radionuclides. In each case, the radioactive material must be isolated from the environment while allowing the use of its radiation. (This is a more severe environment than that of just storage of radionuclides.) Two approaches for safe handling of these materials are used: high-integrity packages and high-integrity radiation forms - similar to CRACHIP in philosophy.

The experience with radioisotopes has been mixed, and major failures have occurred when the package was the only mechanism for material isolation. For example, historically two gamma radiation sources have been used for a variety of industrial applications: ${ }^{60} \mathrm{Co}$ and ${ }^{137} \mathrm{Cs}$. The cesium capsules are doubly encapsulated stainless steal capsules containing cesium chloride, a compound which is soluble in water (ingestion hazard) and potentially in fine particulate form (inhalation hazard). In application, the doubleencapsulated stainless steel capsules have failed. Because of these failures, these capsules have been withdrawn from service. The alternative radiation source, ${ }^{60} \mathrm{Co}$, contains the radioactivity within a metal matrix. The cobalt high-integrity matrix is packaged in capsules. The operational record of cobalt capsules has been good and these capsules have taken over the market for gamma radiation sources.

The experience with cesium capsules raises a second cautionary flag. The cesium capsules were certified, but changes in handling procedures may have led to latter failures. The chemical complexity of the cesium chloride system is equivalent to that of the plutonium metal or plutonium oxide systems, but significantly simpler than any of the plutonium residues-particularly residues containing halogens (chlorides and fluorides). Given the history of the cesium capsules, it may be prudent to have in place a relatively detailed surveillance activity if sealed packages are used to store plutonium in ill-defined forms. 
In the management of radioactive wastes, three approaches for isolation are used in a graded approach. Radioactive wastes containing short-lived radionuclides (e.g., some radionuclides used in medicine) are often stored until they are nonhazardous in special boxes, rooms, or buildings (the vented container). Some lowlevel waste is isolated in sealed packages. The most hazardous wastes, high-level-waste (HLW), will be converted to a stable HLW glass before disposition-equivalent to CRACHIP. 



\section{TECHNICAL CRITERIA}

\subsection{DERIVATION OF TECHNICAL CRITERIA}

The chemical, mechanical, and nuclear criteria for long-term storage of plutonium can be derived from the three health hazards of plutonium: inhalation, ingestion, and direct radiation. There will be separate sets of criteria for the plutonium form, plutonium package, and the storage building. An example of this process is identifying the technical criteria for CRACHIP, as shown in Fig. 2. In this example, the plutonium form is the primary barrier to avoid risks to the worker, public, and environment.

A detailed example of this process is consideration of what plutonium-form storage criteria are necessary to ensure no significant risk of inhalation of plutonium. To avoid inhalation risks, plutonium must not be in a fine particulate form that can become airborne and enter deeply into human lungs. This requirement, in turn, generates four top-level plutonium-form criteria:

- The stored form can not contain fine particles.

- The stored form can not generate fine particles during handling or credible accidents.

- The stored form must be chemically inert. If the plutonium form is chemically reactive, chemical reactions may generate fine particulates.

- The stored form must contain sufficient neutron poisons such that nuclear criticality can not occur with any quantity of the plutonium in any geometry with any type of reflector. Nuclear criticality events generate fine particulates and thus must be avoided if the risk of inhalation is to be minimized.

\subsection{RISK AND TECHNICAL CRITERIA}

\subsubsection{Relationship Between Criteria and Risk}

Technical criteria (when quantified) determine risks of storage. An understanding of technical criteria provides a basis to understand what factors most strongly influence environment, safety, and health (ES\&H). Technical criteria apply to the plutonium form, package, and building. For the discussions herein, the issues associated with the plutonium form will be discussed because of their central roles in ensuring safety-particularly to workers within the facility.

When considering the role of plutonium forms for safe storage, the probability of an accidental release is primarily determined by the probability of failure of the package. If the package does not fail, a release can not occur. Most, but not all package failures occur because of unexpected interactions between the stored material and the package. Plutonium forms that do not interact with the package lower the probabilities of package failure. The consequences of package failure are primarily determined by the characteristics of the plutonium form within the package should the package fail and the contents be dispersed. 


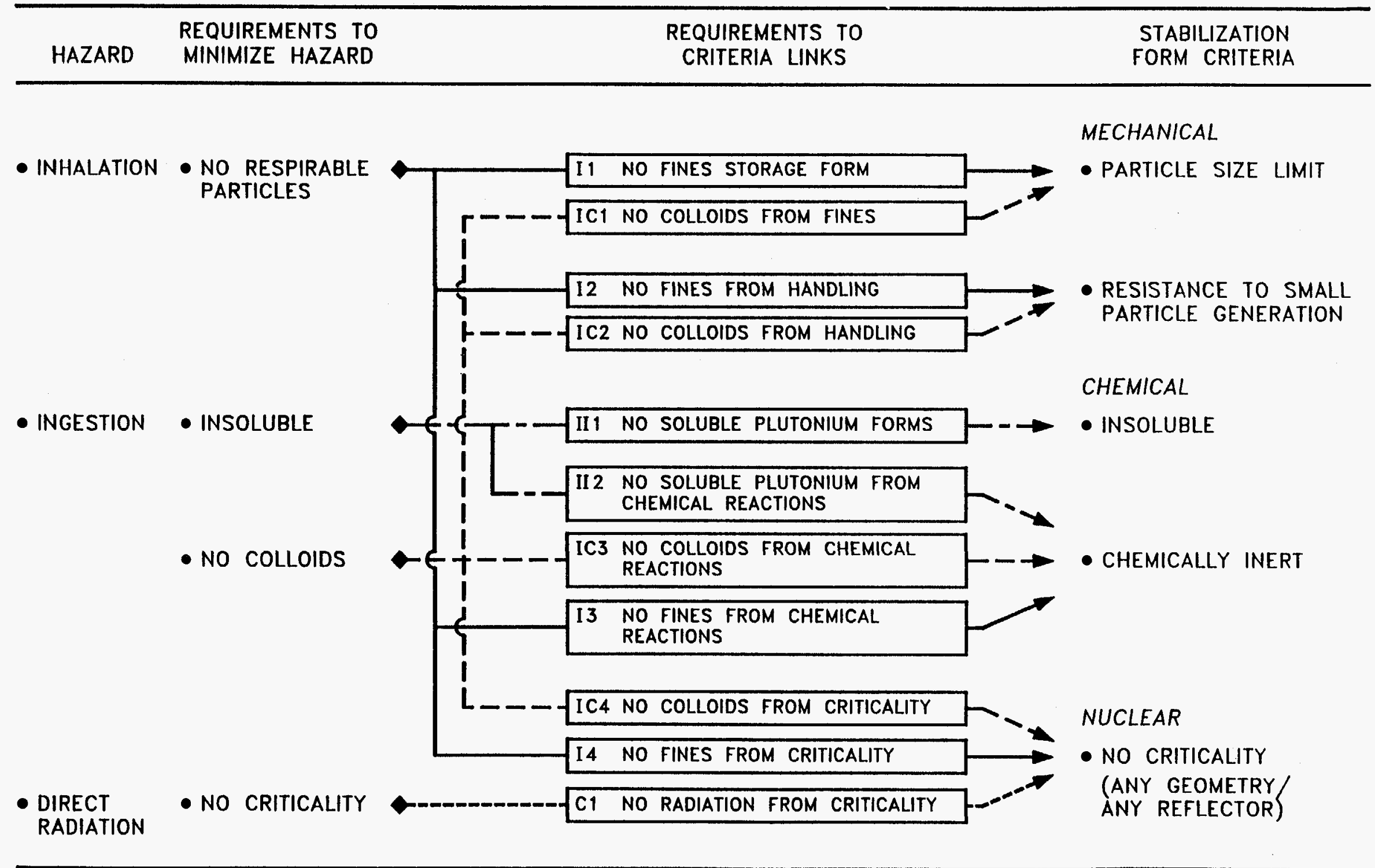

Fig. 2. Long-term plutonium stabilization form criteria based on source of risk. 
The technical criteria for plutonium storage forms are shown in Table 1 with the next lower level of criteria shown. Each type of criteria can lower (a) the probability of package failure, (b) the consequences of package failure, or (c) both the probability and the consequences of package failure. A description of each criteria category is provided (Sect. 7.2.2). In practice, each criteria must be quantified to define acceptable characteristics for plutonium storage forms for each storage option.

Table 1. Relationship between technical screening criteria for plutonium forms and ES\&H risks from storing plutonium (risk $=$ probability $\times$ consequences)

\begin{tabular}{ccc} 
& \multicolumn{2}{c}{ Criteria lowers accident } \\
\cline { 2 - 3 } $\begin{array}{c}\text { Plutonium technical } \\
\text { screening criteria }\end{array}$ & Probability & Consequences \\
\hline $\begin{array}{c}\text { Chemical criteria } \\
\text { Chemically inert }\end{array}$ & Yes & \\
Corrosion & Yes & No \\
Gas release & Yes & Yes \\
Exothermic & No & Yes \\
Solubility & & Yes \\
Mechanical criteria & No & Yes \\
Particle size & No & Yes \\
Low particle generation & Yes & Yes \\
\hline
\end{tabular}

The criteria category descriptions herein describe what the criteria must address, but they do not define the criteria. For example, the gas release criteria to prevent overpressurization of a plutonium storage container may include limits on radiation-induced chemical reactions such as radiolysis of water that yields hydrogen and oxygen. The bottom-level technical criteria may be a material limit such as no more than $\mathrm{x}$ ppm of water by weight within the plutonium form where the value of $x$ depends upon the storage option. 


\subsubsection{Plutonium Form Technical Criteria}

A representative set of technical criteria are described herein for the plutonium form. Similar sets of criteria exist for the package and building.

\subsubsection{Chemical}

Four classes of chemical plutonium-form technical screening criteria can be defined to minimize storage risks: corrosion, gas generation, exothermic reactions, and solubility. The technical screening criteria provide a check list of phenomena to be controlled by controlling allowable chemicals for any plutonium storage option. If the chemical composition is controlled, adverse chemical reactions can be avoided. The degree of control depends upon the storage option. For example, total gas release must be very limited for sealed packages, but for vented containers, the requirement is only to avoid rapid gas generation that exceeds vent capability.

- Corrosion. To avoid package failure, the contents should not corrode the container at a significant rate. An acceptable corrosion rate for several years of storage may be unacceptable for multidecade storage. Corrosion primarily impacts the probability of an accident, not the consequences of an accident. Corrosion may be caused by either the chemical form of the plutonium and associated chemicals or radiation-induced changes in the chemical composition of the plutonium and associated chemicals, over time. There are many examples of radiation-induced chemical reactions. If a package of plutonium is backfilled with air and there is water vapor in the container, radiationinduced chemical reactions will generate nitric acid from air and water, over time. This phenomenon is known from experiments evaluating long-term waste package integrity and radionuclide releases from a waste repository. If chlorides or fluorides are present, other acids may be generated.

- Gas Generation and Release. Excess gas pressures can fail storage containers. Failure of a container under pressure will also disperse the contents of the package and increase the consequences of package failure. Gas generation occurs by three mechanisms: exothermic chemical reactions, radiation induced chemical reactions, and generation of helium resulting from the radioactive decay of plutonium. Gas generation itself does not bring about necessarily a significant increase in container gas pressure. Gas release from the plutonium form depends upon the particulate size of the plutonium material and its chemical structure. Plutonium in glass and large crystal plutonium oxides contain internal lattice sites that hold gases within their structures. The phenomena of gas retention occur in nuclear power plant fuels and HLW glasses in which the matrix traps internally generated gases.

- Exothermic Chemical Reactions. Exothermic chemical reactions can fail packages by heat generation that weakens the package and/or pressure pulses that fail the package. If the package fails, exothermic reactions provide an energy source for dispersion of the package contents. The primary exothermic chemical reaction of concern is detonation of a hydrogen-oxygen gas mixture created by radiolysis of water left within the package. Detonation events can generate short pressure pulses that fail containers. In radioactive waste management operations, this failure mode is a major consideration in the storage of any radioactive material. Multiple approaches are used to ensure that 
it does not happen: (1) spent fuel in sealed storage canisters is vacuum dried to remove water before package sealing, (2) HLW is converted to glass to avoid the possibility of water in the waste, (3) reactor core debris is placed in sealed canisters with multiple chemical recombiners to convert hydrogen and oxygen to water without the risk of explosion (e.g., Three Mile Island core debris storage containers), and (4) mixing liquid HLW and high-speed gas ventilation systems are used to remove potentially explosive gases before they can build up in waste tanks.

- Solubility. The solubility of the plutonium within the package does not impact the probability of package failure, but solubility does impact the consequences of package failure if water is nearby.

\subsubsection{Mechanical}

The mechanical form of the plutonium does not directly impact the probability of package failure. If the mechanical form of the plutonium is a fine powder, it does increase the potential consequences if there is a package failure which allows dispersion of plutonium in air.

In practice, particulate size is indirectly coupled to many other screening criteria. For example, the probability and consequences of most chemical reactions are strongly dependent upon the surface area of the plutonium form. High-surface-area plutonium forms accelerate chemical reactions by two mechanisms:

- Many chemical reaction rates are proportional to the surface area of the plutonium form. The surface catalyzes chemical reactions.

- Many radiation-induced chemical reactions are directly proportional to the surface area of the plutonium. The alpha particle is the primary form of radiation from plutonium. An alpha-particle penetrating energy can be stopped by a single layer of paper. Radiation-induced chemical reactions such as generation of nitric acid are surface area dependent because only on the surface of the plutonium is there significant radiation to induce chemical reactions.

\subsubsection{Nuclear Criticality}

The nuclear characteristics of the plutonium form can strongly influence the probability and consequences of an accident. Plutonium in sufficiently large masses will undergo nuclear criticality that will, in turn, generate heat and pressure sufficient to rupture packages and disperse the package contents. Nuclear criticality can be controlled by the plutonium form (neutron poisons mixed with plutonium) or package/building level criteria. 



\section{PLUTONIUM STORAGE STANDARDS AND STABILIZATION}

Plutonium storage standards have been developed for sealed-package storage of relatively clean plutonium metal and plutonium oxide. ${ }^{5}$ Draft standards ${ }^{6}$ are being developed for storage of plutonium residues in sealed containers. Such standards may or may not allow the use of vented containers. With the adoption of the standards, plutonium stabilization needs can then be defined. 



\section{OTHER CONSIDERATIONS}

\subsection{RISK TRADE-OFFS: REDUCTION OF FAILURE PROBABILITIES VERSUS REDUCTION OF ACCIDENT CONSEQUENCES}

Stabilization activities to meet a single objective may create both advantages and disadvantages. For example, stabilization of metal and scrap to plutonium oxides in a less chemically reactive form with a lower water content is a prerequisite for storage of plutonium as oxide in sealed packages. It prevents internal package corrosion and limits the rate of buildup of pressure within the sealed package-particularly radiolysis of adsorbed water. With some stabilization processes, stabilization may generate a fine plutonium oxide powder that could become an aerosol if the package fails. The package will pressurize with time, and thus an energy source for dispersion is also created. Packaging (and the required stabilization for packaging in this case) provides better isolation (lower probability of package failure), but the plutonium may be in a more hazardous form such that the consequences of package failure may be higher.

Addressing trade-offs such as this specific example depend upon the defined goals for storage. Packaging as the primary isolation barrier for plutonium is the dominant historical approach to plutonium storage because it allows storage of plutonium forms that can be quickly and directly put into the manufacturing process. Storage for future manufacturing may be significantly different than storage for indefinite time periods required when no future use of the plutonium is clearly defined.

\subsection{ECONOMICS}

There are three economic considerations: costs to stabilize plutonium, costs to store it, and R\&D costs. The preferred economic option depends upon multiple factors:

- CRACHIP forms have the lowest storage costs. The absence of significant criticality concerns allows tight packing of CRACHIP forms in vaults minimizing space requirements. CRACHIP forms minimize monitoring requirements. Savings are dependent upon whether there is shortage of vault space and the ensuing need to build new vaults. Vented containers have the highest storage costs.

- Stabilization costs depend upon the specific plutonium form and process options. For plutonium metal, stabilization costs by repackaging in sealed containers are likely to be the low-cost option because little processing or handling is required. For some residues, conversion to a CRACHIP form may be the low-cost stabilization option because some glass processes can handle high levels of impurities in the residues with minimal difficulties while converting the plutonium to glass. Each case must be analyzed based on current technology. 
- Research costs may define the preferred option. It costs money to develop new stabilization processes, but significant resources will also be required to qualify various plutonium forms for different storage options. In particular, the costs to prove that residues are stable for storage may be high. Large research costs and the incentives to avoid such costs can define preferred options.

\subsection{SAFEGUARDS}

Stabilization may impact safeguards with both advantages and disadvantages per different storage modes:

- Homogeneous monolithic forms are simpler to nondestructively assay than are complex mixtures with changing geometries. Sealed packages of plutonium metal and CRACHIP are in the former category.

- Safeguard-tagging systems are simpler to implement with certain storage forms. Sealed containers allow the use of security tags that indicate whether the package has been opened. With some solid forms, platinum or other microspheres can be incorporated into the solid matrix in a random manner. Such microspheres allow X-ray determination of their locations and provide an assurance that the plutonium solid has not been tampered with in any way.

\subsection{PLUTONIUM RECOVERY}

Plutonium is being stabilized for storage. Some of the plutonium will be part of a strategic reserve to allow construction (if required in the future) of added nuclear weapons. Much of the plutonium will be stored until decisions on disposition are made and implemented. For the strategic reserve and some disposition options such as buming plutonium in nuclear power plants, there is the requirement that the plutonium be recoverable from its storage form into a purified form. This can be accomplished for all storage options.

It is noted that if plutonium is stored for long time periods before use, it will have to be purified even if it were initially stored as pure plutonium metal. Plutonium contains ${ }^{241} \mathrm{Pu}$ which decays to ${ }^{241} \mathrm{Am}$ with a 14-year half-life. The buildup of ${ }^{241}$ Am implies increasing radiation levels. The combination of americium buildup and higher radiation levels imply that with multi-decade storage, plutonium purification will be required before use after storage regardless of the storage form chosen.

The CRACHIP glass form allows for two future options: disposition of plutonium glass as a waste or recovery of the plutonium. Storage glasses are designed with the double requirement to be highly insoluble in groundwater but to allow dissolution in strong acids as a method of plutonium recovery. This technology reflects the historical development of such engineered glasses for americium and curium (1) transport, (2) storage, and (3) recovery for reuse. 


\subsection{SCHEDULES}

The time to implement any stabilization option depends strongly upon the plutonium form. For many plutonium forms (e.g., residues), initial stabilization can be conducted, but there will be uncertainties associated with the long-term behavior of the product until long-term accelerated testing can be complete. In most cases, the option exists to initially stabilize the material for storage in vented containers and further stabilize the material at a later date. 



\section{CONCLUSIONS}

With the end of the cold war, the United States will stabilize significant quantities of plutonium for storage. Decisions concerning storage goals will determine what is needed for stabilization. Goals and the implied stabilization activities, in turn, determine needed research to support the achievement of those goals.

Central to stabilization is definition of storage goals. Some types of stabilization activities can be initiated without well-defined goals because (1) there is a general agreement that some current forms of plutonium must be stabilized and (2) the first step in stabilization is clearly defined. Examples of this include converting plutonium containing liquids to solids and convert or remove organics from plutonium storage forms. Beyond these obvious stabilization steps, goals must be defined. The definition of goals involves fundamental policy issues. Some examples of policy issues are:

- How much should ES\&H depend upon human activities into the future? The three examples of different storage options for equivalent levels of worker, public, and environmental safety have very different degrees of dependence upon strict administrative controls, good operations, and steady funding levels. This also has major implications on how many facilities are required at a site to support storage of plutonium.

- Is the goal to minimize plutonium risks (probability of an accident times the consequences of an accident) or to emphasize the avoidance of the higher-consequence accidents?

The major identified storage options are vented containers, sealed packages, and CRACHIP. Multiple options may be selected based on differences between storage sites and multiple national goals. 



\section{REFERENCES}

1. H. F. Dalton, Research Committee For Stabilization of Nuclear Materials, U.S. Department of Energy, Washington D.C., March 15, 1995.

2. U.S. Department of Energy, Defense Nuclear Facilities Safety Board Recommendation 94-1 Implementation Plan, Washington D.C., February 28, 1995.

3. J. Conway, Recommendation 94-1 To The Secretary Of Energy Pursuant To 42 U.S.C. 2286a(5), Atomic Energy Act of 1954 As Amended, Defense Nuclear Facility Safety Board, Washington D.C., May 26, 1994.

4. Merriam-Webster's Collegiate Dictionary: Tenth Edition, Merriam-Webster, Inc., Springfield, Massachusetts, 1993.

5. U.S. Department of Energy, DOE Standard: Criteria For Safe Storage OfPlutonium Metals and Oxides, DOE-STD-3013-94, Washington D.C., December 1994.

6. U.S. Department of Energy, Draft: Criteria for Safe Storage of Plutonium-Bearing Materials (Excluding Metals and Oxides Containing Greater Than 50 Weight Percent Plutonium), DOE-STDDRAFT-SAFT-0045, Washington D.C., May 25, 1995. 

Appendix A:

CRACHIP 



\section{APPENDIX A: CRACHIP}

\section{A.1 BACKGROUND}

CRACHIP is not a new concept. It has been functionally recognized as a transport and storage option for decades. There are many potential CRACHIP storage forms, but only two classes of materials for which the information basis provides high confidence in storage-form performance: (1) glasses and (2) high-fired, high-density MOXs.

If safety is to be ensured by CRACHIP (Fig. 1), three technical criteria must be met:

- Mechanical. A monolithic form is required that does not easily convert to dust when handled or in an accident.

- Chemical. The form must be chemically inert and exhibit low leachability in water.

- Nuclear. The form must contain neutron poisons sufficient such that nuclear criticality can not occur with any quantity or configuration of materials. Neutron poisons are such materials as boron and gadolinium (a rare earth element).

If the CRACHIP product is to be stored in sealed packages, there may be a fourth requirement: the minimization of helium release from the solid. In the CRACHIP forms that have been proposed, this fourth requirement can usually be easily achieved.

\section{A.2 CRACHIP FORMS}

\section{A.2.1 Plutonium Glasses}

Plutonium can be stabilized in special glasses as a CRACHIP form. Two closely related technologies provide the basis for this technological option: worldwide production of HLW glasses and rare earth glasses. Worldwide experience with HLW glasses (cumulative research measured in billions of dollars) indicates that glasses can incorporate most elements including plutonium into a stable form, withstand radiation levels for very long time periods, and trap helium gas generation within the glass matrix. The integrity of the glass is sufficient to trap much of the helium resulting from radioactive decay and thus limit long-term container overpressurization from helium. The specific glasses proposed for plutonium storage are rare earth glasses, which were originally developed for optical lenses. There is an industrial manufacturing experience base for such glasses independent of HLW experience.

Currently, these glasses are being developed by DOE for storage and transport of americium and curium. Solutions of americium and curium at the Savannah River Site (SRS) will be converted to glass and transported to Oak Ridge National Laboratory (ORNL). The americium and curium will be recovered as 
needed from the glass at ORNL and used as target materials in the High Flux Isotope Reactor to create special research isotopes. A type of glass was chosen as the preferred storage and transport form because of a series of properties: (1) acceptance of impure feeds, (2) ease of manufacture, (3) very low solubility in water, (4) chemically inert, (5) acceptable mechanical integrity, (6) ability to handle high heat loads from decay heat, (7) avoidance of nuclear criticality issues when using neutron poisons, and (8) ease of recovery of americium and curium. These characteristics (except chemical recovery) were the basis for glass being chosen and developed as an HLW form and reflect HLW program experience. (Note: The handling difficulties with americium and curium are much more severe than with plutonium; thus, greater incentives exist to use such a material.) All americium and curium operations must be conducted in hot cells because of the resultant high radiation levels. The SRS is also considering glass as a plutonium storage form. Because glasses can accept many elements, glass stabilization allows for the stabilization of many plutoniumcontaining materials without purification of the plutonium being required.

\section{A.2.2 MOXs}

Plutonium can be stabilized as MOX of plutonium, uranium, and rare earth neutron poisons. The base technology for this option is the production of MOX (plutonium oxide and uranium oxide) nuclear fuels. The experience with high-density, high-fired MOX pellets shows the product to be stable, holds helium within the crystal lattice, and can stand high radiation levels for long time periods. This option may require somewhat tighter specification on feed materials in terms of chemical compositions compared to glasses.

\section{A.3 CRACHIP STORAGE}

The major economic incentive for CRACHIP is that it reduces long-term storage costs by altering storage requirements. The elimination of most ES\&H concerns by use of CRACHIP storage implies that the primary requirement for storage of CRACHIP is good security.

CRACHIP may reduce storage volumes. Consider the characteristics of CRACHIP glass. Several factors increase the storage volume required for CRACHIP glass compared to storage of plutonium metal or oxide: lower density $\left(5 \mathrm{~g} / \mathrm{cm}^{3}\right.$ ), a typical plutonium loading in the glass of $10 \%$, and a lower plutonium loading for some residues if the residues are directly converted to glass. Several factors decrease the storage volume required for CRACHIP compared to plutonium metal: monolithic glass cylinders that efficiently fill storage packages, no nuclear criticality considerations, and limited ES\&H concerns. The elimination of nuclear criticality concerns implies that there is no requirement on spacing of the plutonium storage forms in a vault. This allows very different storage systems to be used in a storage vault. 
A conceptual design of a storage block within the vault interior for CRACHIP glass is shown in Fig 3. The layout is similar to some spent fuel storage facilities and certain reactors. The CRACHIP glass is sealed in cans. The cans are stored in horizontal tubes, which lie between vertical shielding walls. The tube length between the shielding walls is $5 \mathrm{~m}$. The tube length and diameter are similar to pressure tubes in Canadian Deuterium Uranium reactors, and the storage vault construction is similar to that used for heat exchangers. The CRACHIP glass can be cooled as necessary by cooling the outsides of the horizontal tubes with air, helium, water, or other fluids. The ends of the tubes in the shield walls have shield plugs that allow manned entry to the loading face of the storage block and may be used to isolate the storage volume from the manned entry areas. The vault may be loaded and unloaded manually or with stacker-retrieval devices. The primary barrier to plutonium release is the CRACHIP glass; next are can, storage tube, and vault.

Assuming a 5-m-high storage block, 10-cm-diam CRACHIP glass, $5-\mathrm{g} / \mathrm{cm}^{3}$ glass density, a triangular storage tube array, $20-\mathrm{cm}$ spacing between center lines of storage tubes, $80 \%$ of storage tube length filled with glass, and $100 \mathrm{t}$ of glass with $10 \mathrm{t}$ of plutonium, the length of the storage block would be $5 \mathrm{~m}$. The storage layout allows each dimension to be increased; thus doubling dimensions expands capacity by a factor of 8. This type of high-density storage vault can only be used when the plutonium form contains sufficient neutron poisons that nuclear criticality control is not a vault requirement. 


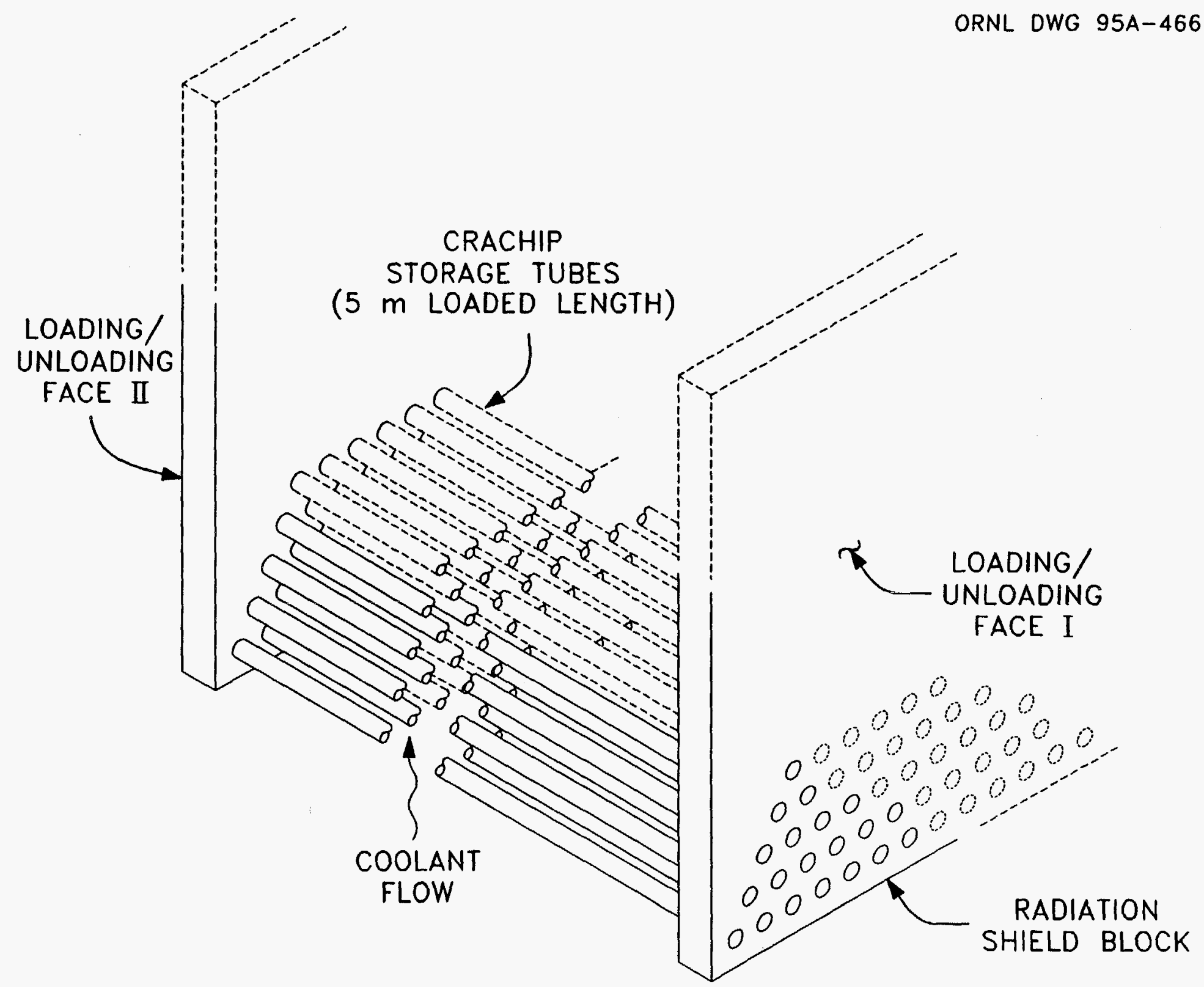

- Fig. 3. CRACHIP storage block within plutonium storage vault. 


\section{INTERNAL DISTRIBUTION}

1. C. W. Alexander

2. E. C. Beahm

3. J. M. Begovich

4. S. O. Cox

5. A. G. Croff

6. K. R. Elam

7. D. A. Everitt

8-12. C. W. Forsberg

13. T. M. Gilliam

14. S. R. Greene

15. M. J. Haire

16. J. A. Klein

17. A. M. Krichinsky

18. S. B. Ludwig

19. L. E. McNeese

20. G. E. Michaels
21. H. J. Monroe

22. J. P. Nichols

23. G. W. Parker

24. C. V. Parks

25. R. B. Pope

26. W. J. Reich

27. D. E. Reichle

28. J. C. Rudolph

29. K. A. Williams

30-31. Central Research Library

32-33. Laboratory Records

34. Laboratory Records-RC

35. ORNL Y-12 Technical Library

36. Document Reference Section

37. ORNL Patent Section

\section{EXTERNAL DISTRIBUTION}

38. John Baker, U.S. Department of Energy, Trevion II Building, Room 334, 12800 Middlebrooke Rd., Germantown, Maryland 20874.

39. Mark Bronson, Lawrence Livermore National Laboratory, MS L-460, 7000 E. Ave., Livermore, California 94550.

40. Garry H. Bryan, Battelle Blvd., Richland, Washington 99352.

41. Leslie Burris, Argonne National Laboratory, 9700 S. Cass Ave., Bldg. 205/CMT, Argonne, Illinois 60439.

42. H. R. Canter, U.S. Department of Energy, Office of Fissile Materials Disposition, 1000 Independence Ave., S.E., Washington, DC 20585.

43. Lisa Chan, Forrestal Bldg, MD-3, 3F-042, Washington, DC 20585.

44. A. I. Cygelman, U.S. Department of Energy, Office of Fissile Materials Disposition, 1000 Independence Ave., S.E., Washington, DC, 20585.

45. Hank Dalton, U.S. Department of Energy, EM-60, GA-242, 1000 Independence Ave., Washington, DC 20585. 
46. William Danker, U.S. Department of Energy, Office of Fissile Materials Disposition, 1000 Independence Ave., S.E., Washington, DC, 20585.

47. Mark Dinehart, Los Alamos National Laboratory, Warehouse SNM30, MS E511, Bikini Rd., Los Alamos, New Mexico 87545.

48. Don Duston, Department of Energy-Rocky Flats, T124A, C-26, P O Box 928 , Golden, Colorado 80402-0928.

49. Randy Erickson, Department of Energy, Materials Disposition 2, 3F-042, 1000 Independence Ave., Washington, DC 20585.

50. Rowland E. Felt, MS 2430, Box 1625, Idaho Falls, Idaho 83415.

51. Frank R. Graham, Bldg. 773A - C144, P. O. Box 616, Aiken, South Carolina 29808.

52. Amold Guevara, U.S. Department of Energy, EM-60, GA-242, 1000 Independence Ave., Washington, DC 20585.

53. Bob Kenley, Forrestal Bldg., EM-60, GA-242, Washington, DC 20585.

54. Bernard R. Kokenge, BRK Associates, 5233 S. Clayton Rd., Farmersville, Ohio 45325.

55. Leroy Lewis, Lockheed Idaho Technologies, MS 5210, Box 1625 , Idaho Falls, Idaho 83415.

56. Mal McKibben, Westinghouse Savannah River Co., Bldg. 773-41A, Aiken, South Carolina 29808.

57. G. W. Ramsey, Westinghouse Savannah River Co., P.O. Box 616, Aiken, South Carolina 29808.

58. Tom Rising, EG\&G RF, MS T-130B, Cactus \& Hwy 93, Golden, Colorado 80402-0464.

59. Jack Ryan, Pacific Northwest Laboratory, MS P7-25, 902 Battelle Blvd., Richland, Washington 99352.

60. Carl Sink, U.S. Department of Energy, EM-60, GA-242, 1000 Independence Ave., Washington, DC 20585.

61. I. Kent Sullivan, Westinghouse Savannah River Co., Bldg. 773-41A, Aiken, South Carolina 29808.

62. John Tseng, U.S. Department of Energy, Office of Environmental Restoration and Waste Management, Trevion II Building, 1000 Independence Ave., S.E., Washington, DC 20585. 
63. John R. Weeks, Battelle National Laboratory, Bldg. 475 C, P.O. Box 5000, Upton, New York 11973-5000.

64. Alan K. Williams, Consultant, 2453 Bear Den Rd., Frederick, Maryland 21701.

65. Clint Wolfe, WSRC, Bldg. 773-A216, Aiken, South Carolina 29808.

66. Office of Assistant Manager of Energy Research and Development, P.O. Box 2008, DOE-ORO, Oak Ridge, TN 37831-6269.

67-68. Office of Scientific and Technical Information, P.O. Box 62, Oak Ridge, TN 37831. 